\title{
Predicting climate-induced changes in groundwater resources on the basis of hydrogeological model research: Case study of the Carpathian flysch belt
}

University of Wroclaw, Institute of Geological Sciences, Department of Hydrogeology, Pl. M. Borna 9, 50-204 Wroclaw E-mail: *sebastian.buczynski@ing.uni.wroc.pl; **marek.wcislo@ing.uni.wroc.pl

The level of water in aquifers depends mostly on precipitation. However, recent research has shown that greater annual rainfall values do not necessarily trigger off an automatic increase in groundwater recharge. The lowering of the water table may result not only from lower precipitation, but also from intensification in evaporation and a decreased natural infiltration capacity of drieddown soil. Also extreme rainfall conditions (such as torrential rain and storms) that occur in mountainous regions may, owing to a rise in surface runoff and decreased infiltration, lead to a lower groundwater recharge.

Studies seem to indicate that in the upper drainage basin of the river Muszynka (southern Poland) a tenyear period of precipitation equal to $62 \%$ of the longterm average is likely to cause the groundwater levels (present in the Palaeogene flysch formations) to drop by two metres in river valleys and 40 metres in watershed zones and central parts of slopes. This will result in a reduction of groundwater resources related to aquifer compressibility makes up only $3.4 \times 10^{-5} \%$ of the annual underground runoff; therefore, it is not necessary to include it in the overall water balance.

\section{Introduction}

Climate change is a naturally occurring process. Over the past million years, it has been known to induce extended periods of extremely hot, cold or mild temperatures. These alterations, caused by regional or extra-terrestrial processes, occurred very gradually (Aaby, 1976). In the $20^{\text {th }}$ century, however, their rate began to increase rapidly. Since 1861, the mean temperature of the Earth's surface rose by only $0.6-1.8^{\circ} \mathrm{C}$, but, alarmingly, half of the observed growth rate took place during the last thirty years (Nicholls et al., 1996; Zhang et al., 2000).

Similar tendencies towards an increase in temperatures and the occurrence of extreme events such as intense precipitation or longlasting droughts have been observed in the Carpathian basin (Bartholy and Pongrácz, 2007). Analyses of meteorological data (1946-2001) from the Carpathian Basin (Bartholy and Pongrácz, 2007) and from the Lesser Poland Province between 1951-2000 (Lupikasza and Bielec-Bakowska, 2005) have shown growth in the frequency, time of duration and intensity of heat waves, as well as a surge in the number of incidents of heavy rainfall. The number of days with precipitation exceeding 10-20 $\mathrm{mm}$ has risen, while a drop has been observed in the number of days when the volume of rainfall was lower than 5,1 and $0.1 \mathrm{~mm}$. During that period a marked increase in and continuous extension of the HWDI (heat wave duration index) could be discerned. The number of days with temperatures exceeding $20^{\circ} \mathrm{C}$ has also risen.

The authors of the IV IPCC Report predict that in the 21st century these trends will continue; in milder climates, this may lead to an increased frequency, duration and intensity of heat waves and a greater risk of droughts and heavy rainfall (Meehl et al., 2007). Between 1990 and 2100 the global temperature of the air is predicted to go up by $1-5.8^{\circ} \mathrm{C}$ (Nyirfa and Harron, 2001; Showstack, 2001). Observations and prognoses concerning the changes are hotly debatated by the international community, as climate alterations may impair the infiltration of water, which in turn would have disastrous effects on groundwater and could diminish the yield of wells (Rivard et al., 2003; Tranberth et al., 2007; Apaydin, 2009).

Long-term studies of groundwater levels and precipitation contributed to an increase in the number of reports, some of which concern Poland as well. Their aim is to analyse the alterations in the groundwater table that have occurred over an extended period of time. Apart from presenting patterns in the groundwater regime, the authors often attempt to plot visible trends in the occurring changes and determine their cause, usually with the use of elementary statistical parameters. Chelmicki's work concerning Poland (1986, 1991), which include data from 1961-1980, have shown that the water table has risen in most of the country. More localised reports, such as Dynowska and Pietrygowa's (1978) from the upper river Vistula basin, Kazimierski's (1999) from the Masovian Plain or Guzik's et al. (1999) from the Cracow-Silesian Region, based on the analyses of data from up to 25-year-long periods, have also shown a rise in groundwater levels. According to the authors, this tendency may be a result of an increase in overall rainfall (Dynowska and Pietrygowa, 1978; Chelmicki, 1986, 1991) combined with a decrease in groundwater exploitation (Guzik et al., 1999; Kazimierski, 1999).

Dabrowski's (1997) analysis of the renewability of Greater Poland's tertiary groundwater body has shown, at the same time, the opposite, downward trend for the water table in the high plain of Sroda. In the years 1975-1982, the rate of water table lowering was 
equal to $0.17 \mathrm{~m} / \mathrm{year}$, while during the period of 1983-1993 it rose to $0.47 \mathrm{~m} /$ year. It was only in 1994 that the rate of water loss began to fall, although Dabrowski attributes this more to a reduction in the exploitation of groundwater rather than a growth in precipitation.

In his twenty-year (1961-1980) study of the Sudeten and subSudeten region, Tarka (1997) has not recorded any statistically important changes in the level of groundwater. He also claims that the predicted change of Poland's mild climate to a more continental one would have no effect on the groundwater table of the Sudeten region. Górski and Przybylek (1997) are of a different opinion: the increase of precipitation in winter and a decrease in summer (characteristic of a more continental climate) may diminish the amount and quality of existing groundwater and surface water resources, particularly during long periods of summer droughts.

The aim of this research was to examine the ways in which a computer-generated hydrogeological model could be used to predict changes in water resources that might occur as a result of a diminished overall precipitation. A hydrogeological model of the upper Muszynka drainage basin was constructed in order to help with the research (the river is in Poland and is the Poprad's right-bank tributary). The project allowed predictions concerning fluctuations in the groundwater resources in the flysch region of the Beskid Sadecki mountain range during a hypothetical ten-year period of extremely poor recharge.

\section{Location and climate}

The drainage basin that has been covered by the hydrogeological model is $53 \mathrm{~km}^{2}$ (Figure 1) and includes the river Muszynka's catchment area up to the profile in Powroznik. The area under study lies in the Lesser Poland Province, in the south, near the Slovakian border. The north-western, northern and north-eastern borders of the area run along the drainage divide of the Wojkowski, Bradowiec, Goliczny and Roztoka streams, while the southern and south-eastern boundaries are marked by the Polish border (and, coincidentally, the watershed of the river Muszynka). The southern and western parts of the this area lie within the Popradzki Landscape Park, which was established in 1987 in order to protect the cultural and biological qualities of the Sadecczyzna region.

Altitudinal zonation can be discerned here, as in the entire Carpathian region, which is connected with the elevation of the target area (even up to $900 \mathrm{~m}$ ). The lowest, moderately warm zone reaches up to $600-650 \mathrm{~m}$ above sea level and is marked by the annual isotherm of $6^{\circ} \mathrm{C}$. The next zone (reaching $1100 \mathrm{~m}$ above sea level), marked by an average annual temperature of $4^{\circ} \mathrm{C}$, shows features of a moderately cold climate. The highest altitudes constitute the cold zone, with an annual isotherm of only $2^{\circ} \mathrm{C}$ (Okolowicz and Martyn, 1989). The warmest month in the year is July, with an average temperature of $14.6^{\circ} \mathrm{C}$, while January's average temperature of $-6.3^{\circ} \mathrm{C}$ makes it the coldest month of the year. The number of days with snow cover varies from 63 to 154 . The frequent occurrence of ground-frost during early autumn and late spring has a negative impact on the local environment; this phenomenon is intensified by the inversion of air temperature.

The annual rainfall reaches $849 \mathrm{~mm}$ at the meteorological station in Krynica Zdrój. Seasonal differences can be detected in the pattern of precipitation: during spring and in summer, rainfall increases, while a significant drop in precipitation can be observed in autumn and winter. The highest precipitation occurs between May and August; the lowest values can be traced from October to March. The wettest

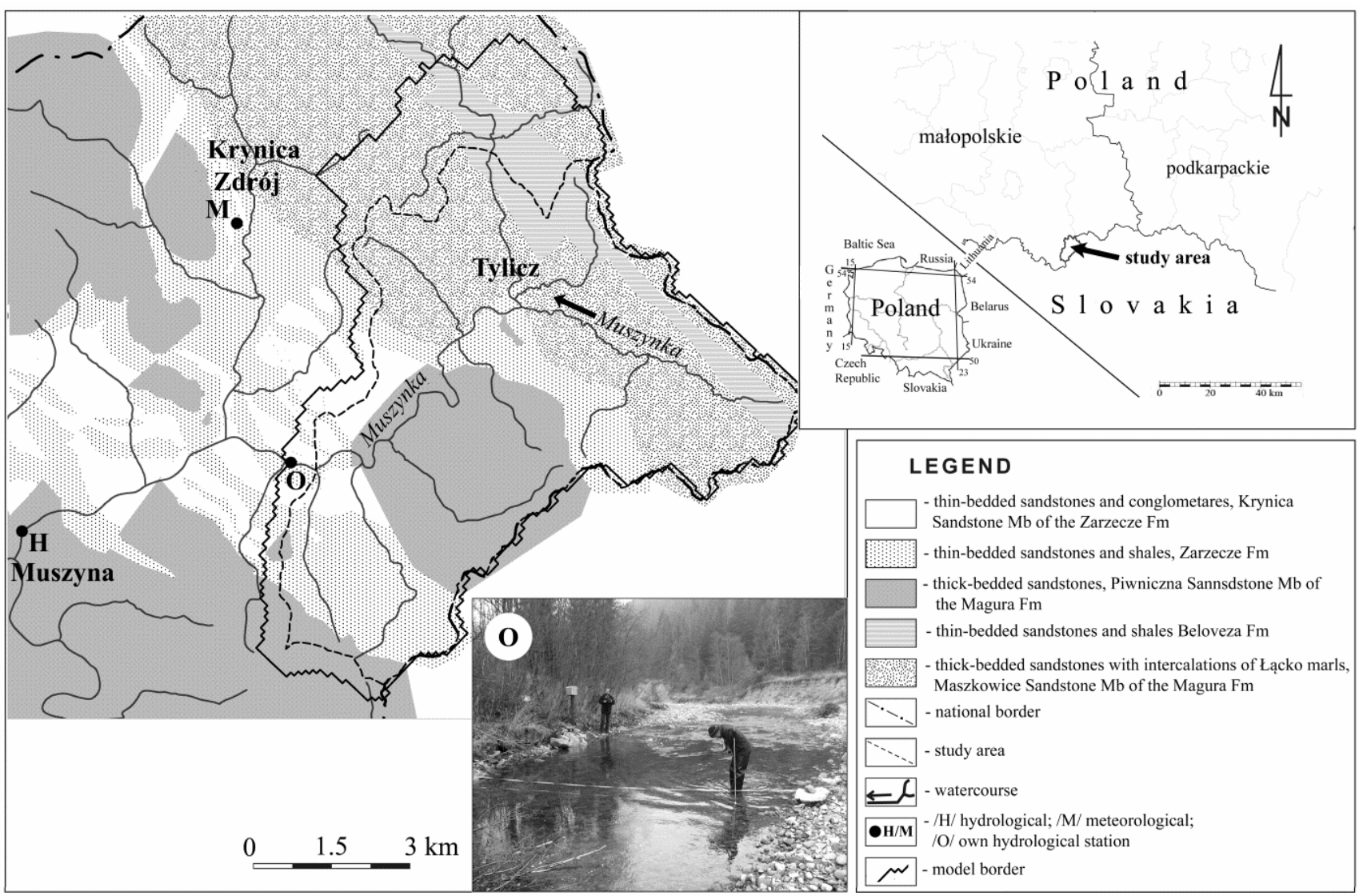

Figure 1. Study area: Drainage basin of the upper Muszynka River; insert shows its location in Poland. Geological structure based on Oszczypko (2006). 
month is July, when mean precipitation values reach $116 \mathrm{~mm}$; during the driest months, November and December, only $45-49 \mathrm{~mm}$ of rainfall can be observed. Maximum diurnal precipitation reaches 40-42 mm. The year 2010 was unusual in this respect: the 3rd of June saw a maximum diurnal precipitation reaching a staggering $118 \mathrm{~mm}$.

\section{The geology and hydrogeology of the area under study}

The area stretches over the south-eastern part of the Magurska Nappe, where two subunits, Sadecka and Krynicka, join together. The geological profile exhibits sediments from the middle and late Eocene epoch. The Sadecka subunit includes schists from Labowa, as well as the Beloweska, Zeleznikowska and Magurska formations. The sandstone-dominated Krynicka subunit incorporates the Szczawnicka, Zarzecka and Magurska formations. The Krynicka subunit exhibits a fold-and-boulder structure, while the southern part of the Sadecka subunit is a secondarily folded syncline. Two main tectonic zones extend over this area, bordered by tectonic fault lines parallel to Krynica and perpendicular to Tylicz (Birkenmajer, 1986; Birkenmajer and Dudziak, 1988; Birkenmajer and Oszczypko, 1989; Oszczypko 1991, 1998; Oszczypko et al., 1999).

According to Paczyñski (1995), the area subjected to prognostic research is part of the Carpathian hydrogeological region (XIV). Here, the largest groundwater resources can be found mostly in river valleys, mountain dales and, to a smaller extent, in flysch facies formations. Previous research has shown that the range and thickness of quaternary alluvial deposits in the mountainous section of the Muszynka's drainage basin is low (1-15m) and creates a local source of groundwater (Szczepañski and Szklarczyk, 2005). The largest groundwater resources occur within tertiary flysch rocks. Flysch rocks do not exhibit typical aquifer formations; the presence of water resources is associated with sub-surface fissures and weathered rocks (often of varying ages). As previous research shows, the lowest border of circulation and fresh groundwater exchange reaches depths of 60$80 \mathrm{~m}$, depending on the rock type and morphology (Chowaniec, 2006), or up to $100 \mathrm{~m}$ (Witczak and Duñczyk, 2004).

The amount of water retained in the flysch rocks is determined by the shape and porosity of sandstone units. Extensive studies have shown that the effective porosity of sandstone from Piwniczna and Maszkowice is low (1-10\%), while the storage coefficient fluctuates between $1.06 \times 10^{-4}-1.06 \times 10^{-5}$ (Krawczyk, 2010a, b). Tectonic activity and weathering create favourable conditions for the development of cracks and fissures, which in turn have a positive effect on the microhydraulic properties of flysch rocks. Despite the negative correlation between the rate of water exchange and depth, the pressure distribution resulting from the morphological structure of land indicates that there is a possibility of slow water exchange even at depths of $1500 \mathrm{~m}$ (Witczak and Duñczyk, 2004; Zuber and Chowaniec, 2009). The test-obtained hydraulic conductivity of the fracturedporous medium vary between $1,13 \cdot 10^{-4}$ and $1,25 \cdot 10^{-9} \mathrm{~m} / \mathrm{s}$ (Nalêcki et al., 2004). Jetel (1986), after analysing the results of pumping tests, proposed the following formula describing the relationship between the hydraulic conductivity and depth:

$$
\mathrm{K}_{\mathrm{H}}=\mathrm{K}_{0} \mathrm{e}^{-\mathrm{aH}}
$$

where $\mathrm{K}_{\mathrm{H}}$ - hydraulic conductivity at the depth of $\mathrm{H}[\mathrm{m} / \mathrm{s}] ; \mathrm{K}_{0}-$ hydraulic conductivity of the surface $[\mathrm{m} / \mathrm{s}]$; a - empirical coefficient, based on research of the Beskidy area (Ciezkowski et al., 1999) $[1 / \mathrm{m}] ; \mathrm{H}-$ depth $[\mathrm{m}]$

\section{Methods}

Having assumed that the levels of the water table and groundwater resources are strictly connected with the amount of precipitation (Mustonen, 1986; Apaydin, 2009; Korhonen and Kuusisto, 2010), the first stage of the research included collection of data on hitherto occurring rainfall. According to the World Meteorological Organization (WMO), the climate of a given area or region is defined on the basis of mean values calculated over an extended period of time. In order to obtain reliable results, it is advisable to have access to data that have been recorded for many consecutive years (30 is the minimum, according to the WMO; Mrugala and Shuber, 2004). The data used in the article come from a weather station in the valley of the river Kryniczanka, in the centre of Krynica, approximately five kilometres away from the drainage basin under study (Fig.1). Figures concerning the annual and monthly volume of precipitation were collected during the years 1891-1930 and 1955-1998. Drawing on this information, it was possible to deduce the region's pattern of precipitation and determine the amount of rainfall during dry or extremely dry periods. To do this, two methods were employed: the Relative Precipitation Index and the Standardised Precipitation Index, both of which are very popular and widely used throughout Poland. Two methods had to be used, because Gasiorek and Musial (2011) proved that classification based on the Relative Precipitation Index (RPI) is not equivalent to that based on the Standardised Precipitation Index (SPI).

The former (RPI) is based on the ratio between the total amount of precipitation during a given period of time and the long-term mean value for that region. The RPI laid the foundations for the establishment of criteria for years and seasons in Poland, making it possible to identify given periods as extremely dry or humid (Kaczorowska, 1962). The application of the Relative Precipitation Index when attempting to establish how much rainfall a certain month received (whether there was an abundance or deficiency) is discussed in many papers (Kosiba, 1948; Tomaszewska, 1994; Zurek, 2007). After an exhaustive and thorough research, Kaczorowska (1962) managed to classify humidity levels for different seasons (and the whole year) and divide years into the categories summarized in Table 1.

The other method used to evaluate precipitation in the target area was the Standardised Precipitation Index (SPI), which has been quoted in literature worldwide. The SPI index is used in the USA by the National Drought Mitigation Center, and in Europe, e.g. in Hungary,

Table 1. Classification of precipitation conditions according to the relative precipitation index and standardised precipitation index SPI and corresponding probabilities for SPI

\begin{tabular}{|c|c|c|c|c|}
\hline Period & RPI & $\begin{array}{l}\text { RPI is not } \\
\text { equivalent } \\
\text { to SPI }\end{array}$ & SPI & $\begin{array}{c}\text { Probability } \\
\%\end{array}$ \\
\hline Extremely dry & $<50 \%$ & & $=-2.0$ & 2 \\
\hline Very dry & $50-74 \%$ & & {$[-2.00 ;-1.50)$} & 4 \\
\hline dry & $75-89 \%$ & & {$[-1.50 ;-0.50)$} & 25 \\
\hline normal & $90-110 \%$ & & {$[-0.5 ; 0.5)$} & 38 \\
\hline wet & $111-125 \%$ & & {$[0.5 ; 1.5)$} & 25 \\
\hline Very wet & $126-150 \%$ & & {$[1.5 ; 2)$} & 4 \\
\hline Extremely wet & $>150 \%$ & & $=2$ & 4 \\
\hline
\end{tabular}


Italy and Spain, where it has become a standard tool to identify periods of drought and to estimate their intensity (McKee et al., 1993, 1995). The use of SPI in Poland was first suggested by Labêdzki (2006). The main virtue of this approach is that it facilitates the evaluation of rainfall conditions in various climates, regardless of the time scale. The SPI of any region is determined after analysing long series of precipitation over a certain period of time. The system of classifying rainfall conditions in Poland using the SPI, suggested by Labêdzki (2006), along with the probability of the occurrence of certain periods, is presented in Table 1.

The articles can be found two methods of counting SPI (McKee et al., 1993, 1995). One of them - the method of SPI evaluation relies on counting the value: $x=\Phi^{-1}(F(x)$ ), where $F$ is a distribution function of gamma distribution with parameters estimated on the basis of analyzed data set, and $\Phi$ is a distibution function of standardized normal distribution. In practice, the following fact is often taken into account: for a random variable $\mathrm{X}$ gamma distibuted, variable $\mathrm{Z}={ }^{3} \mathrm{VX}$ has aproximately normal distribution (Krishnamoorthly et al., 2008). With the use of this method, SPI for annual precipitation sums in the years 1955-1998 were evaluated by the formula:

$$
S P I=\frac{Y-\bar{x}}{d}
$$

where, $\mathrm{Y}$ - random variable, whose values ??are the annual precipitation sums (x) after transformation $\mathrm{x} ?^{3} \mathrm{vx}$, transforming the distribution gamma in normal distribution. $\bar{x}$ - stands for the mean value of the normalised precipitation series. $\mathrm{d}$ - standard deviation of the normalised precipitation series.

Extensive research (Mustonen, 1986; Korhonen and Kuusisto, 2010) has demonstrated that the discharge regime depends mainly on precipitation and is strictly correlated with it.

A correlation between annual precipitation and discharge was calculated so as to establish the interdependence of variables in this drainage basin. The records of the flow of the river Muszynka helped to estimate the size of underground runoff in the event of an extremely dry year. The data on the daily flow of the river were amassed at a station in the town of Muszyna /H/ in the years 1955-1984 (Fig.1). The IMGW (Institute for Meteorology and Water Resources) stream gauge is located $600 \mathrm{~m}$ from the point where the Muszynka joins the river Poprad, and the surface area of the drainage basin of that region is equal to $148 \mathrm{~km}^{2}$.

With access to the observations of low, medium and high discharge, it is possible to establish characteristic values indicative of underwater runoff:

- low mean annual discharge (SNQr), calculated for given years as the arithmetic mean of the lowest monthly discharges;

- low mean long-term discharge (SNQw), calculated as the arithmetic mean of SNQr discharges.

Model simulations were performed as the next stage of research, following an analysis of the changeability of climate. The results concerning the predicted rainfall for an extremely dry year, along with its corresponding underground runoff (SNQr discharge) provided direct entry data for the regional model. They later laid the groundwork for predictions concerning hypothetical conditions of rainfall deficiency.

The completed model was then verified: simulations were done without any water withdrawal, thus allowing for the recreation of pseudo-natural conditions without the necessity of intensive exploitation. The model's water balance and the obtained results concerning the state of the water table became the keystone for further testing and verification, as well as simulative prognostic research.

\section{Conceptual model}

The hydrological system of the Tylicz area is complex. This is partly due to the limited and fragmentary knowledge of the region's hydrological conditions, as well as the limited continuity and many layers of the hydro-structural formation, in which particular flysch sequences are connected mostly by dip joints and larger tectonic zones. Further complications arise because of the extremely complex and varied nature of the conditions of groundwater retention (pores and fissures) and a high hydraulic gradient (around 60 metres per kilometre). These characteristics make the flysch environment a difficult challenge for researchers and one rarely taken on; it is also problematic when it comes to the realisation of a numerical model. The boundaries of the modelled area were based on topographical watershed lines of surface streams. Previous works (Ciezkowski et al., 1999; Druzkowski, 2000, 2001) have proved that these borders are remarkably consistent with the watershed lines of groundwater. However, the boundaries of the modelled area were moved several hundred metres away from these lines in order to allow an unrestrained development of watershed zones and prevent the planned groundwater catchment simulation from exerting any influence over the groundwater watershed lines.

The documents and materials necessary for the construction of a drainage basin model include: (i) geological and tectonic data (Oszczypko, 2006; Graniczny et al., 2007), as well as stratigraphic sections (profiles) of wells; (ii) data concerning static and dynamic water tables and the exploitation of groundwater; (iii) data collected during hydrogeological mapping (Buczyñski et al., 2007) and documentations of the results of pumping tests in the key region and its perimeters. Stationary observations of water flow discharge in the marked-out drainage basin were carried out in order to estimate the total water balance $/ \mathrm{O} /$ (Fig.1).

In total, 67 boreholes exist within the target region and the immediate vicinity. They provide useful information about the geological structure, water table located during drilling, the stabilised water table and thickness of aquifers, as well as the resources and yield of wells. A small number of boreholes were used to calculate the hydraulic conductivity (13 boreholes) and the storage coefficient ( 2 boreholes). Within the complex hydrological structure of the flysch formations, the values may, nevertheless, be not strictly compliant with the actual parameters, due to the difficulties in defining the exact thickness and sequence of the aquifers, which constitute many connected hydrologic deposits, some of which are more permeable than others. Such a complex system could only be depicted using a deterministic-stochastic model. It is a very efficient strategy which takes into account all of the above-mentioned limitations (Berkowitz, 2002). Areas of minor or unrecognised fissures and fractures were regarded, like the rock matrix, as a porous environment, while larger tectonic structures were recognised as regions with a lowered or elevated, and often anisotropic, hydraulic conductivity (MartinezLanda and Carrera, 2005). The upper, porous groundwater environment from the Quaternary Period was omitted in the process of modelling due to its insignificantly small distribution.

The range of the hydraulic conductivity reflects clearly the geological structure. For the requirements of the model, five uniform domains of the hydraulic conductivity were established, each allocated 
Table 2. Hydraulic conductivity of particular litho-facial units

\begin{tabular}{|l|l|l|l|l|l|}
\hline & $\begin{array}{l}\text { Lackie } \\
\text { units }\end{array}$ & $\begin{array}{l}\text { Units from } \\
\text { Zarzecze }\end{array}$ & $\begin{array}{l}\text { Sandstone } \\
\text { from } \\
\text { Piwniczna }\end{array}$ & $\begin{array}{l}\text { Krynickie } \\
\text { sandstones }\end{array}$ & $\begin{array}{l}\text { Beloweskie } \\
\text { units }\end{array}$ \\
\hline $\mathrm{k}(\mathrm{m} / \mathrm{s})$ & $8.00 \mathrm{E}-07$ & $5.32 \mathrm{E}-07$ & $1.60 \mathrm{E}-06$ & $9.26 \mathrm{E}-07$ & $5.32 \mathrm{E}-07$ \\
\hline
\end{tabular}

to a particular litho-facial unit. The range of these domains was determined with the help of pumping tests in the boreholes, located at a depth of around 40-80 $\mathrm{m}$ (Table 2). The exponential decrease of hydraulic conductivity along the increasing depth (the hydraulic conductivity at a depth of around $80 \mathrm{~m}$ is equal to $2-5 \cdot 10^{-11} \mathrm{~m} / \mathrm{s}$ ) and the mean storage coefficient value, which reaches $5.8 \cdot 10^{-5}$ (Krawczyk, 2010b), were also taken into account.

Recharge of the flysch system occurs in the peak and slope parts of river valleys (Duliñski et al., 2006). Cracks and fissures within sandstones and mudstones of the flysch region enable slow percolation of water. The amount of precipitation reaching the deepest layers depends therefore mostly on the lithology of the vadose water zone. The lithological characteristics of tertiary geo-structural units are largely responsible for the distribution of recharge sources, which is why every unit was allocated a fixed recharge coefficient, whose value was determined in a way that would help to reach the intended level of groundwater runoff from the target area. Accurate and reliable precipitation mapping was required to determine the spatial changeability of recharge.

Mean rainfall values are clearly suggestive of a correlation between the precipitation and the location of the observation (measuring) post (Stasko et al., 2007). The correlation coefficient of nine different stations was equal to 0.89 . Following this correlation, a map of precipitation was made at hypsometric cuts every 100 metres. Later, with the help of GIS, the precipitation map was plotted over the geological map with its separate infiltration coefficient domains. The allocation of particular infiltration coefficients was performed by means of the trial-and-error method, until compatibility with the underground discharge was reached.

\section{Groundwater model}

The model was developed applying the Visual Modflow software, a commonly known tool that enables water balance studies (McDonald and Harbaugh, 1988). A discretisation grid was used for the construction of the model. 194 rows and 148 columns were divided every 50-100 m, most densely in the central part of the model, where groundwater exploitation is being continuously carried out.

The upper boundaries of the model were fixed with regard to the morphology of the terrain; interpolation methods were employed to transfer the land surface model to the numerical model. Seven numerical layers of constant thickness were subsequently outlined in order to illustrate the downward trend in the hydraulic conductivity. Thanks to this operation, the model may be classified as fully threedimensional. The lower border of the model (type $\mathrm{Q}=0$ ) runs at a depth of about $600 \mathrm{~m}$ and includes the deepest water reserves that lie in close proximity to the area. The remaining boundaries were moved slightly beyond the border of the drainage basin in order to minimise the feedback processes. General-head boundary (GHB) was established for these borders. The total area of land incorporated in the model was equal to $70.4 \mathrm{~km}^{2}$ (Fig. 1). The recharge was depicted using a constant flux boundary condition, while the third-type boundary condition was applied with regard to the course of rivers and springs.

\section{Calibration of the model}

The calibration process was performed in steady, exploitationfree conditions. Trial-and-error calibration was done on the basis of 18 springs. Stable and high-yielding springs were chosen for the calibration process, because they tend to provide the most accurate depiction of the hydraulic head of the flysch system and are usually evenly distributed. An initial spatial distribution of the hydraulic conductivity, obtained from the available data (13 measurements) was then verified. Given, however, that the initial data came from the wells that were located in areas of heightened hydrological parameters, the hydraulic conductivity had to be lowered during calibration (Table 3).

Table 3. Post-calibration values of the hydraulic conductivity [m/s]

\begin{tabular}{|l|l|l|l|l|l|l|}
\hline $\begin{array}{l}\text { Layer } \\
\text { thick- } \\
\text { ness })\end{array}$ & $\begin{array}{l}\text { Lackie } \\
\text { layers }\end{array}$ & $\begin{array}{l}\text { Layers } \\
\text { from } \\
\text { Zarzecze }\end{array}$ & $\begin{array}{l}\text { Sandstone } \\
\text { from } \\
\text { Piwniczna }\end{array}$ & $\begin{array}{l}\text { Krynickie } \\
\text { sandstones }\end{array}$ & $\begin{array}{l}\text { Beloweskie } \\
\text { layers }\end{array}$ & $\begin{array}{l}\text { Slate } \\
\text { rocks }\end{array}$ \\
\hline $\begin{array}{l}130 \mathrm{~m}) \\
(70 \mathrm{~m})\end{array}$ & $6.90 \mathrm{E}-07$ & $7.70 \mathrm{E}-07$ & $3.00 \mathrm{E}-07$ & $9.60 \mathrm{E}-08$ & $7.70 \mathrm{E}-08$ & $9.00 \mathrm{E}-08$ \\
\hline $\begin{array}{l}3 \\
(100 \mathrm{~m})\end{array}$ & $4.40 \mathrm{E}-08$ & $6.10 \mathrm{E}-08$ & $1.00 \mathrm{E}-07$ & $6.90 \mathrm{E}-08$ & $6.10 \mathrm{E}-08$ & $6.00 \mathrm{E}-09$ \\
\hline $\begin{array}{l}4 \\
(100 \mathrm{~m})\end{array}$ & $1.80 \mathrm{E}-08$ & $1.20 \mathrm{E}-08$ & $3.60 \mathrm{E}-08$ & $2.10 \mathrm{E}-08$ & $1.20 \mathrm{E}-08$ & $1.00 \mathrm{E}-09$ \\
\hline $\begin{array}{l}5 \\
(200 \mathrm{~m})\end{array}$ & $7.30 \mathrm{E}-09$ & $4.90 \mathrm{E}-09$ & $1.50 \mathrm{E}-08$ & $8.50 \mathrm{E}-09$ & $4.90 \mathrm{E}-09$ & $3.30 \mathrm{E}-10$ \\
\hline $\begin{array}{l}6 \\
(200 \mathrm{~m})\end{array}$ & $3.20 \mathrm{E}-10$ & $2.20 \mathrm{E}-10$ & $6.50 \mathrm{E}-10$ & $3.30 \mathrm{E}-10$ & $2.20 \mathrm{E}-10$ & $2.20 \mathrm{E}-10$ \\
\hline $\begin{array}{l}7 \\
(400 \mathrm{~m})\end{array}$ & $4.00 \mathrm{E}-11$ & $4.00 \mathrm{E}-11$ & $4.00 \mathrm{E}-11$ & $4.00 \mathrm{E}-11$ & $4.00 \mathrm{E}-11$ & $4.00 \mathrm{E}-11$ \\
\hline
\end{tabular}

The following calibration targets were reached: a normalised root mean squared (NRMS) lower than $0.97 \%$, an absolute residual mean (ARM) of $2.0 \mathrm{~m}$, and a root mean squared (RMS) of $2.59 \mathrm{~m}$. The resulting water balance of the model (Table 4) indicates that the groundwater discharge corresponds with the observed underground runoff values. A major contribution of recharge sources to the water balance clearly indicates that the exchange of water between neighbouring areas is very limited, which in turn proves that the process of water resource formation occurs solely within the model.

\section{Modification of the model}

The calibrated model was then used to determine the effect of low recharge on the water balance, the new hydraulic head distribution

Table 4. Water balance model of the Tylicz area $\left(F=70.4 \mathrm{~km}^{2}\right)$

\begin{tabular}{|l|l|l|l|}
\hline Inflow & {$\left[\mathrm{m}^{3} / \mathrm{d}\right](\%)$} & Runoff & {$\left[\mathrm{m}^{3} / \mathrm{d}\right](\%)$} \\
\hline $\begin{array}{l}\text { Effective recharge } \\
\text { (infiltration) }\end{array}$ & $\begin{array}{l}35,444.14 \\
(97.7)\end{array}$ & $\begin{array}{l}\text { Bore } \\
\text { exploitation }\end{array}$ & $\begin{array}{l}879.10 \\
(2.4)\end{array}$ \\
\hline $\begin{array}{l}\text { Recharge from } \\
\text { rivers }\end{array}$ & $\begin{array}{l}479.01 \\
(1.3)\end{array}$ & $\begin{array}{l}\text { River drainage } \\
\text { Spring drainage }\end{array}$ & $\begin{array}{l}32,688.41 \\
(90.1)\end{array}$ \\
\hline $\begin{array}{l}\text { From neighbouring } \\
\text { regions }\end{array}$ & $355.01(1.0)$ & $\begin{array}{l}\text { Into neighbouring } \\
\text { regions }\end{array}$ & $\begin{array}{l}2,713.60 \\
(7.5)\end{array}$ \\
\hline Sum & $36,278.16$ & Sum & $36,281.11$ \\
\hline$\%$ error & 0.02 & \multicolumn{2}{|l}{} \\
\hline
\end{tabular}


and groundwater resources. The recharge in particular zones was proportionally lowered; the model was re-calculated in steady-state conditions and the results were compared with those obtained in conditions of average recharge.

Considering the exploitation of water resources, it is unarguably essential to relate the obtained value of water table lowering to the amount of water corresponding to that decrease. A transformed version of the storage coefficient formula was used to calculate that value (Heath, 1987):

$$
S=\frac{d V_{w}}{d h} \frac{1}{A}
$$

Transformed formula:

$$
d V_{w}=A S d h
$$

where S stands for storage coefficient (storavity); dV, for volume of released water; $\mathrm{dh}$, for change in average hydraulic head; A-area, for equals river basin area.

An analogous technique was used to calculate the $\mathrm{dV}$ volume of water, which was a result of the subtraction of the static water table map from the dynamic water table map (in conditions of water exploitation).

\section{Results}

At the IMGW (Institute for Meteorology and Water Resources) station in Krynica, the average annual precipitation during the years 1955-1998 was equal to $845 \mathrm{~mm}$ : only $8 \mathrm{~mm}$ lower than the annual average calculated for the period between 1891-1930. The long-term mean value was therefore equal to $849 \mathrm{~mm}$ (Table 5). The findings paved way for the assessment of precipitation during dry, very dry and extremely dry years (with the help of the Relative Precipitation Index) and the figures seem to indicate that in an extremely dry year, the total rainfall will not exceed $425 \mathrm{~mm}$; during a very dry year precipitation values will oscillate between 425 and $628 \mathrm{~mm}$ (an average of $526 \mathrm{~mm}$ ), while during a dry year these values will not exceed $756 \mathrm{~mm}$ (Table 5).

Slightly different values were obtained when the SPI method was applied. In the target part of the Muszynka's drainage basin the precipitation during an extremely dry year will not exceed $592 \mathrm{~mm}$;

Table 5. Precipitation depth during dry, very dry and extremely dry years

\begin{tabular}{|c|c|c|}
\hline Period & $1891-1930$ & $1955-1998$ \\
\hline $\begin{array}{l}\text { Mean annual rainfall/Minimal annual } \\
\text { rainfall }\end{array}$ & $\begin{array}{l}853 \mathrm{~mm} / \\
557 \mathrm{~mm}\end{array}$ & $\begin{array}{l}845 \mathrm{~mm} / \\
647 \mathrm{~mm}\end{array}$ \\
\hline $\begin{array}{l}\text { Mean annual rainfall during the target } \\
\text { periods }\end{array}$ & \multicolumn{2}{|l|}{$849 \mathrm{~mm}$} \\
\hline \multicolumn{3}{|l|}{ Relative Precipitation Index (RPI) method } \\
\hline $\begin{array}{l}\text { Extremely dry year }(<50 \% \text { of the mean } \\
\text { annual rainfall during the target periods) } \\
\text { Very dry year (from } 50 \text { to } 74 \% \text { of the mean } \\
\text { annual rainfall) } \\
\text { Dry year (from } 74 \text { to } 89 \% \text { of the mean } \\
\text { annual rainfall) }\end{array}$ & \multicolumn{2}{|c|}{$\begin{array}{l}\text { from } 425 \text { to } 628 \mathrm{~mm} \\
\text { (average: } 526 \mathrm{~mm} \text { ) } \\
\text { from } 628 \text { to } 756 \mathrm{~mm}\end{array}$} \\
\hline \multicolumn{3}{|c|}{ Standardised Precipitation Index (SPI) method } \\
\hline $\begin{array}{l}\text { Extremely dry }(=-2.0) \\
\text { Very dry }[-2.00 ;-1.50) \\
\text { Dry }[-0.5 ; 0.5)\end{array}$ & \multicolumn{2}{|c|}{$\begin{array}{l}<592 \mathrm{~mm} \\
\text { from } 592 \text { to } 648 \mathrm{~mm} \\
\text { from } 648 \text { too } 771 \mathrm{~mm}\end{array}$} \\
\hline
\end{tabular}
presented against the average and minimal rainfall at the Krynica station. in a very dry year, values will vary from 592 to $648 \mathrm{~mm}$, while a dry year will not have rainfall higher than $771 \mathrm{~mm}$ (Table 5).

In order to predict changes in water balance, the recharge value resulting from the estimation of annual rainfall during a very dry year (using the RPI method) was inserted into the regional model. The adopted average value is that for a very dry year (at $526 \mathrm{~mm}$, which is $62 \%$ of the long-term mean precipitation depth). In the case of the SPI method, $526 \mathrm{~mm}$ is the value predicted for an extremely dry year.

Other important data processed in the modification of the regional model of the upper Muszynka drainage basin were those showing the flow rate of the river at the Muszyna station (the area of the dewatered drainage basin was equal to $148 \mathrm{~km}^{2}$ ). Low mean annual discharge values (SNQr) varied from $0.46 \mathrm{~m}^{3} / \mathrm{s}$ in 1969 to $1.21 \mathrm{~m}^{3} / \mathrm{s}$ in 1975 , while the long-term value from 1955-1984 period (SNQw) was equal to $0.83 \mathrm{~m}^{3} / \mathrm{s}$. These discharge values correspond to a certain extent with the groundwater runoff from the drainage basin in the event of 849 mm-high precipitation.

The correlation coefficient between annual precipitation and runoff indicates a strong interdependence $(r=0.72)$, which is statistically significant. The coefficient of determination $\mathrm{R}^{2}$ equals 0.51 . The linear regression between the average runoff and mean precipitation is shown in Figure 2.

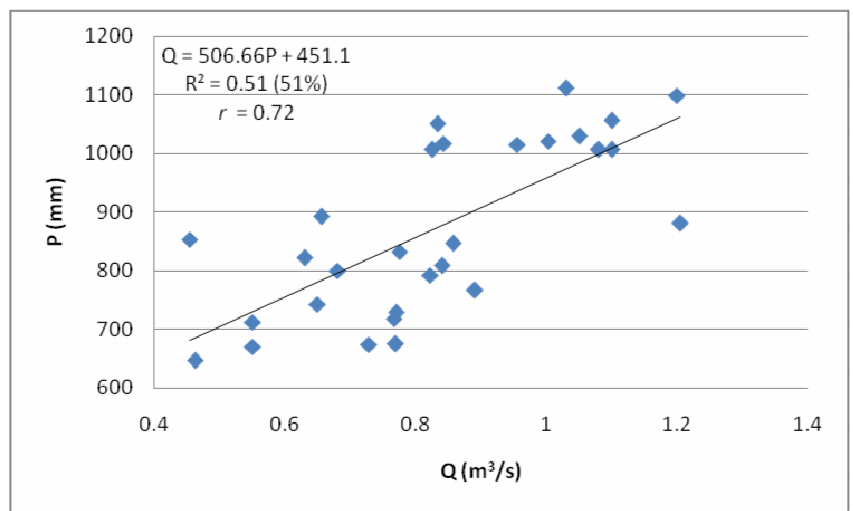

Figure 2. Scattergram plot of annual precipitation $(P)$ vs annual mean runoff in the river Muszynka catchment $(Q)$ in 1955-1984.

The clearly visible correlation between precipitation and discharge seems to indicate that runoff from the drainage basin is proportional to rainfall intensity. Therefore, it can be postulated that $526 \mathrm{~mm}$-high precipitation, which constitutes $62 \%$ of the long-term average, would induce runoff whose value would also come close to the $62 \%$ of the long-term mean low flow (SNQw). During the construction of the model it was assumed that the groundwater runoff during a very dry year would, on average, total $0.51 \mathrm{~m}^{3} / \mathrm{s}$ for an area of $148 \mathrm{~km}^{2}$. After transferring that value onto the target area of the Muszynka drainage basin, whose surface area is equal to $53 \mathrm{~km}^{2}$, an groundwater runoff value of $0.17 \mathrm{~m}^{3} / \mathrm{s}$ was obtained, which is tantamount to a modulus of groundwater runoff equal to $3.1 \mathrm{~L} / \mathrm{s} / \mathrm{km}^{2}$.

The analysis of precipitation allowed the estimation of recharge during a very dry year; it may, on average, be equal to $526 \mathrm{~mm} \mathrm{(62 \%}$ of the long-term average) by RPI standards. That decrease was confirmed after the analysis of groundwater runoff from the area under study during the years 1955-1984. As the hydrogeological model shows, the groundwater level is predicted to drop as a result of low recharge (Figure 3). These changes might be significant and include 
the whole of the area. The average value of groundwater table lowering may be equal to $26 \mathrm{~m}$. However, in watershed zones and central parts of slopes, that value may reach an alarming $40 \mathrm{~m}$. The groundwater table was not predicted to drop very significantly in the drainage areas, where most of the wells are located. In the Muszynka valley, the predicted average value of groundwater table lowering was equal to $2 \mathrm{~m}$, while in valleys carved by smaller streams the values varied from 5 to $10 \mathrm{~m}$.

Given that the mean storage coefficient (storavity) $\mathrm{S}$ of the area is equal to $8.5 \cdot 10^{-5}$, the surface area of the hydrogeological basin is $53.3 \mathrm{~km}^{2}$ and the change in average hydraulic head after the lowering of recharge equals $26 \mathrm{~m}$, it is estimated that groundwater table lowering could lead to a drop in the amount of water within the hydrogeological massif (dV) by $80,346 \mathrm{~m}^{3}$.

The difference between the volume of water $(\mathrm{dV})$ in very dry and normal years is very small, constituting only $0.67 \%$ of the annual

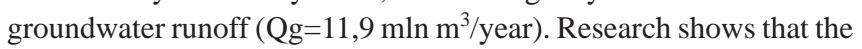
retention of water in deep aquifers does not play an important role in the shaping of the total water balance.

Similarly, the difference between the volume of water $\mathrm{dV}$,

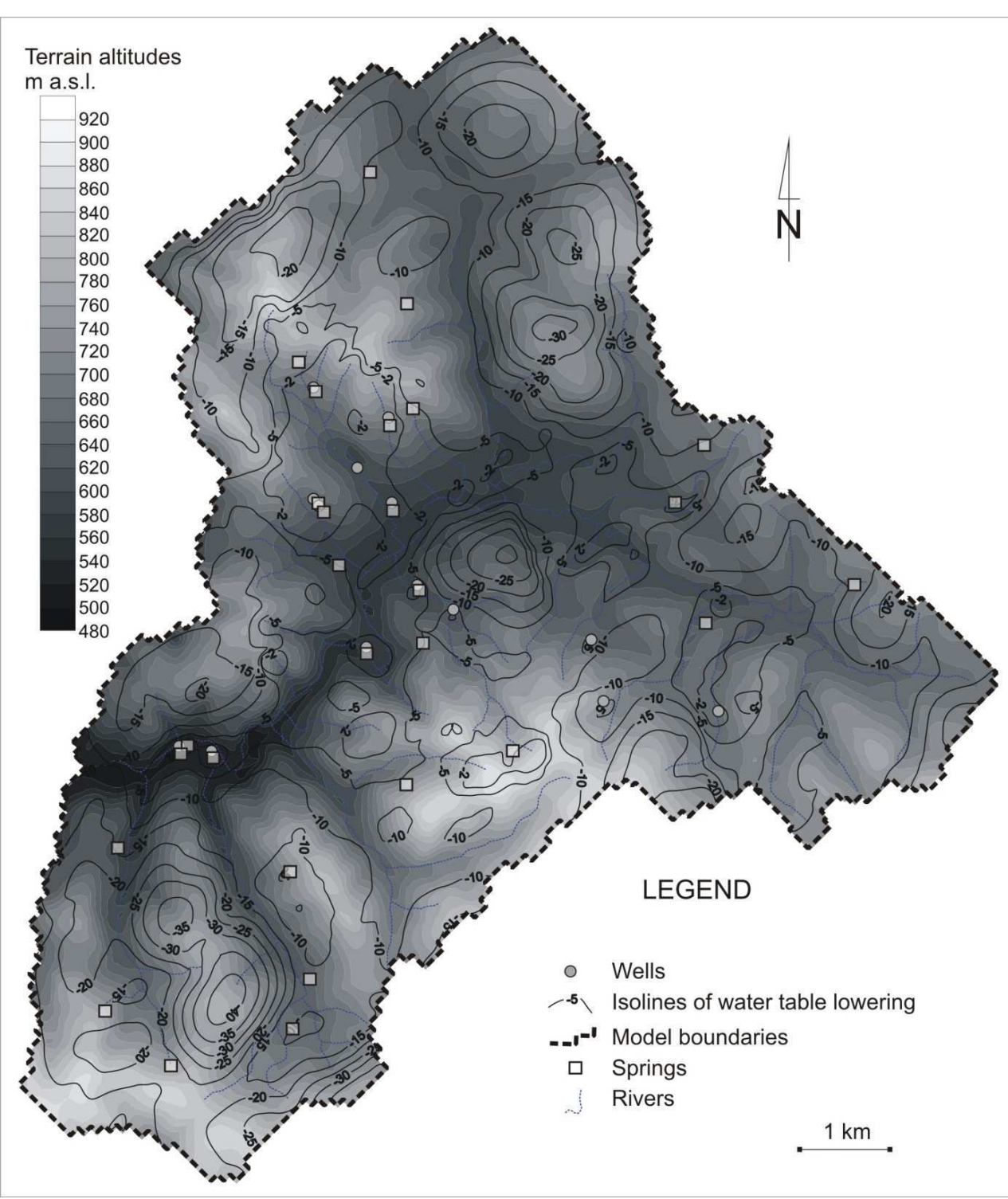

Figure 3. Prognosis of water table lowering by low recharge. calculated by subtracting the static water table from the dynamic table (in conditions of exploitation), was also fairly small (only $401 \mathrm{~m}^{3}$ ):

$$
\mathrm{dV}=53.28 \mathrm{~km}^{2} \cdot 5.8 \times 10^{-5} \times 0.13 \mathrm{~m}=401 \mathrm{~m}^{3}
$$

This figure reflects the lowering of groundwater resources related to aquifer compressibility (retention) resulting from exploitation. The effect of exploitation of deep-lying resources is very small compared to the impact of a very dry year (around $0.5 \%$ ). The decrease in the amount of static resources due to exploitation constitutes only $3.4 \times 10^{-5} \%$ of the annual groundwater runoff, and therefore does not have to be included in the total water balance.

\section{Discussion}

Previous studies (Druzkowski, 2001; Loáiciga, 2003; Woldeamlak et al., 2007; Apaydin, 2009; Radhakrishnan and Elango, 2011) clearly indicate that potential climate change may have a negative impact on groundwater resources. Results of model studies in the case of a dryyear scenario predict that the Grote-Nete catchment area is likely to experience a drop in average annual groundwater levels equal to $0.52 \mathrm{~m}$. The highest predicted values may reach $3.1 \mathrm{~m}$, which, in the authors' view (Woldeamlak et al., 2007), could pose a threat not only to fields and grasslands, but also to bushes and trees with shallow root systems. As shown by Woldeamlak et al., (2007), the most significant lowering of the groundwater table occurred outside river valleys and marshlands. Groundwater discharge areas have, nonetheless, decreased by $28 \%$, which might lead to the gradual disappearance of swamps and marshes. While working on shallow aquifers in the Minor River Basin, Radhakrishnan and Elango (2011) found that the lowering of the groundwater table was most significant in areas far from the sea. By contrast, coastal regions experienced only very small variations in the volune of groundwater. Apaydin (2009) and Buczyñski et al. (2006) noted however that shallow aquifers, particularly those consisting of unconsolidated sediments, were more susceptible to changes in resources and fluctuations of the groundwater table. Similarly, shallow aquifers are affected by local climate changes, whereas deep aquifers are affected only by regional changes.

Research done by the authors in the upper drainage basin of the river Muszynka indicates that the lowering of the groundwater table occurs in deep aquifers as well. Their studies also showed that these fluctuations can be significant and may vary depending on the area that is being analysed. Should 
$526 \mathrm{~mm}$-high precipitations ( $62 \%$ of the long-term average) continue for a hypothetical period of 10 years, the average lowering of the groundwater table might be equal to $26 \mathrm{~m}$. These values, though, could reach $40 \mathrm{~m}$ in watershed zones and central parts of slopes: 1015 times more than for shallow aquifers (Woldeamlak et al., 2007). The varying morphology of the terrain, along with its significant differences in height, contributes to such a high rate of water table lowering.

The trend was analogous for deep aquifers: the least intensive groundwater table lowering occurred in drainage areas (river valleys), but the reverse was true for the Muszynka valley and valleys carved by smaller streams, with the figurers varying from about 2 metres to 5-10 metres respectively.

The findings seem to indicate that, owing to the nature of the aquifer, the predicted lowering of the groundwater table will not have a significant impact on the overall amount of water in the massif. The water volume is likely to drop by only $80,346 \mathrm{~m}^{3}$, which constitutes $0.67 \%$ of the annual underground runoff. The difference in the volume of water, as defined by the subtraction of the static water table from the dynamic table (in conditions of exploitation), is equal to $401 \mathrm{~m}^{3}$, demonstrating that the decrease of static resources resulting from exploitation constitutes only $3.4 \times 10^{-5} \%$ of the annual underground runoff and can therefore be ignored when calculating the total water balance.

The research also shows that the morphology of land and the nature of aquifers both affect the lowering of the groundwater table. When the horizontal distance between the recharge zone and drainage area is small but the difference in height is considerable, the lowering of groundwater levels is significant; much greater than e.g. on plains. The nature of the dominant rock (non-porous sandstone) contributes to the lowering of groundwater levels and large fluctuations of the water table.

The process of groundwater table lowering should not contribute to the depletion of groundwater resources, however, as most of these are located in valleys, where the water table is predicted to fall by only $2 \mathrm{~m}$.

It should also be pointed that underground reserves of particular groundwater circulation systems (local, transitional and regional) are in constant hydraulic contact with one another; the occurrence of the situation observed and described by Loáiciga (2003) is therefore quite probable. According to him, the combined effect of recharge deficiency and intensive water withdrawal can lead to a long-term decrease in spring yield, resulting in a local, shallow groundwater circulation system below an ecologically threatening threshold (stress threshold). Interestingly, he also observed that in an average year (no recharge deficiency), the volume of groundwater resources rises, notwithstanding the intensification of water withdrawal.

Although no negative environmental impact associated with groundwater exploitation was observed in the Muszynka's upper drainage basin, it is necessary to monitor the spring yield and the level of water in wells in order to preserve the hydrodynamic and hydrochemical balance of the region. Such groundwater monitoring would not only provide invaluable scientific data, but also facilitate proper response to environmental changes and adjustment of the output of wells to the acceptable drawdowns.

\section{Acknowledgements}

This work was supported in part by ING contribution 1209/M/
ING/11. The authors wish to express their gratitude to the CCHBC for allowing access to vital data. Constructive comments by professor Stanislaw Stasko, and Tomasz Mateñko are deeply appreciated.

\section{References}

Aaby, B., 1976, Cyclic climatic variations in climate over the past 5,500 yr reflected in raised bogs: Nature, v. 236, pp. 281-284.

Apaydin, A., 2010, Response of groundwater to climate variation: fluctuations of groundwater level and well yields in the Halacli aquifer (Cankiri, Turkey): Environ Monit Assess, v. 165, pp. 653-663.

Bartholy, J., and Pongrácz, R., 2007, Regional analysis of extreme temperature and precipitation indices for Carpathian Basin from 1946 to 2001: Global and Planetary Change, v. 57, pp. 83-95.

Birkenmajer, K., 1986, Stages of structural evolution of the Pieniny Klippen Belt, Carpathians: Studia Geol. Polon., v. 88, pp. 7-32.

Birkenmajer, K., and Dudziak, J., 1988, Age of Palaeogene flysch in the Pieniny Klippen Belt, Carpathians, Poland, based on calcareous nannoplankton: Bull. Pol. Acad. Sci., Earth Sci., v. 36, pp. 15-24.

Birkenmajer, K,. and Oszczypko, N., 1989, Cretaceous and Palaeogene lithostratigraphic units of the Magura Nappe, Krynica Subunit, Carpathians: Annales Societatis Geologorum Poloniae, v. 59, pp. 145181 .

Berkowitz B., 2002, Characterizing flow and transport in fractured geological media: A review. Advances in Water Resources. v. 25, pp. 861-884.

Buczyñski, S., Stasko, S., and Tarka, R., 2006, Dynamika stanów wód podziemnych na przedpolu Sudetów na przykladzie stacji w Zebrzydowie (Dynamics of the hydraulic heads on the Sudety Mountains Foreground - the Zebrzydów station): Wspólczesne Problemy Hydrogeologii, t. XII, Toruñ, pp. 71-75.

Buczyñski, S., Olichwer, T., Tarka, R., and Stalko, S., 2007, Zawodnienie formacji fliszowej Karpat w oparciu o wyniki badañ zródel Beskidu Krynickiego w rejonie Tylicza (Water bearing of Carpathian flysch formation base on springs research in Krynicki Beskid-Tylicz region): Wspólczesne Problemy Hydrogeologii, t. XIII, cz. 2, Kraków-Krynica, pp. 403-412.

Ciêzkowski, W., Józefko, I., Schmalz, A., and Witczak, S, 1999, Dokumentacja hydrogeologiczna ustalajaca zasoby eksploatacyjne wód leczniczych oraz dwutlenku wêgla (jako kopaliny towarzyszacej) ze zloza w uzdrowisku Krynica oraz ustalajaca zasoby dyspozycyjne wód podziemnych (zwyklych, leczniczych i o wlaœciwoœciach leczniczych) w zlewni Kryniczanki (Hydrogeological documentation establishing the admissible volume of extracted groundwater of medicinal water and carbon dioxide (as the accompanying mineral) from the field in the spa town of Krynica and determine groundwater disposable resources (fresh, medicinal and medicinal properties) in the catchment Kryniczanka): Politechnika Wroclawska, Wroc ${ }^{3}$ aw.

Chelmicki, W., 1986, Wieloletnia tendencja zmian zwierciad³a wód gruntowych w Polsce w latach 1951-1978 (The long-term tendency of the groundwater level in Poland in the period of 1951-1978): Zesz. Nauk. UJ., Prace Geograficzne, z. 67, pp. 25-31

Chelmicki, W., 1991, Zmiany polozenia zwierciadla wód gruntowych na tle zmian opadów atmosferycznych w latach 1961-1980 (Changes in groundwater level in relation to changes of precipitation in the years 1961-1980): Zesz. Nauk, UJ, Prace Geograficzne, z. 88, pp. 77-85.

Chmal, H., 2004, Nowa metoda prognozowania powodzi w dorzeczu Odry (A new method of flood forecasting in the Odra basin). Przeglad Geologiczny, v. 52, nr 11, pp. 1096-1097.

Chowaniec, J., 2006, Hydrogeologia Karpat (Hydrogeology of the Carpathians), Przeglad Geologiczny, v. 54, nr 10, pp. 846-847.

Dabrowski, S., 1997, Odnawialnosc trzeciorzêdowego zbiornika wód podziemnych Wielkopolski (Renewal of groundwater flow system of drainage basin Wieprza and Przymorze in regional hydrogeological prospection): Wspólczesne Problemy Hydrogeologii, t. VIII, Poznañ, pp. 33-39.

Druzkowski, M., 2000, Variability of natural effluents as an indicator of 
groundwater retention in the Carpathian foothills (southern Poland): Environmental Geology, v. 40 (1-2), pp. 90-98.

Druzkowski, M., 2001, The Influence of Natural and Human-Related Factors on the Water Circulation in the Carpathian Foothills (southern Poland): Water Resources Management, v. 15 (2), pp. 93-108.

Dubicki, A., ed., 2002, Zasoby wodne w dorzeczu górnej i srodkowej Odry w warunkach suszy (Water resources in the basin of the upper and middle Odra River dry weather): Instytut Meteorologii i Gospodarki Wodnej, Warszawa, 107 pp.

Duliñski, M., Kuc, T., Zuber, A., and Mróz, H., 2006, Badania stêzenia trytu oraz skladu izotopowego prób wód z obszaru Tylicza pobranych w pazdzierniku 2006 roku wraz z wstêpna interpretacja wyników (Tritium concentration and isotopic composition of water samples collected from the area Tylicz in October 2006 with preliminary interpretation of the results): Tow. Badania Przemian Srodowiska Geosfera.

Dynowska, I., and Pietrygowa, Z., 1978, Wieloletnie fluktuacje zwierciadla wód gruntowych w dorzeczu górnej Wisly (Long-term period fluctuations in groundwater levels in the upper basin of the Vistula): Czasopismo Geograficzne, t. 49, z. 2, PWN, Warszawa.

Gasiorek, E., and Musial, E., 2011, Porównanie i klasyfikacja warunków opadowych na podstawie wskaznika standaryzowanego opadu i wskaznika wzglêdnego opadu (Comparsion and classification of precipitation conditions based on standardized SPI and relative RPI precipitation indices): Water-Environment-Rural Areas z. 4 (36), pp. $107-$ 119.

Górski, J., and Przybylek, J., 1997, Wplyw suszy w latach 1989 -1992 na warunki eksploatacji infiltracyjnych ujêc wody w dolinie Warty (The influence of 1989-1992 years drought on exploitation conditions of infiltration water intakes in the Warta River valley): Wspólczesne Problemy Hydrogeologii, t. VIII, Poznañ, pp. 1-8.

Graniczny, M., Piatkowska, A., and Kowalski, Z., 2007, Elaboration of the lineament (photolineament) map of the "Tylicz I" mining area: HYDROKONS, Warszawa.

Guzik, M., Liszka, P., and Pacholewski, A., 1999, Interpretacja wieloletnich wyników pomiarów zwierciadla wód podziemnych wybranych poziomów wodonoœnych regionu Slasko-Krakowskiego (The interpretations of the long term observations of the water table in the selected aquifers of the Silesian - Cracow region): Wspólczesne Problemy Hydrogeologii, t. IX, Kielce, pp. 89-104.

Heath, R.C., 1987, Basic ground-water hydrology: U.S. Geological Survey Water-Supply Paper 2220.

Hoelting, B., 1980, Hydrogeologie (Hydrogeology). Ferdinand Enke Verlag, Stuttgart.

Jetel J., 1986, Vertical variation in permeability of flysh rocks in the Czechoslovak Carpathians. Kwart. Geol., 29, 1, pp. 167-178.

Kaczorowska, Z., 1962, Opady w Polsce w przekroju wieloletnim (Precipitation in Poland in the long-term period): Przeglad Geograficzny IG PAN. Nr 33, 112 pp.

Kazimierski, B., 1999, Dynamika stanów wód piêtra trzeciorzêdowego centralnej czêsci Niecki Mazowieckiej (Dynamics of the hydraulic heads in the tertiary aquifer system in the central part of the Mazovian Basin): Wspó ${ }^{3}$ czesne Problemy Hydrogeologii, t. IX, Kielce, pp. 431-434.

Konoplancew, A., and Siemionow, S.M., 1979, Prognozowanie i kartograficzne odwzorowanie re ¿imu wód gruntowych (Forecasting and cartographic representation of the groundwater regime): Wydawnictwa Geologiczne, Warszawa, 235 pp.

Korhonen, J., and Kuusisto, E., 2010, Long-term changes in the discharge regime in Finland: Hydrology Research, v. 41, No 3-4, pp. 253-268.

Kosiba, A., 1948, Klimat ziem Slaskich (Climate Silesian lands): Zagadnienia Gospodarcze Slaska, seria II. Wydaw. Inst. Slas, 127 pp.

Krawczyk J., 2010a, Dokumentacja hydrogeologiczna ustalajaca zasoby eksploatacyjne ujec wód podziemnych niebêdacych kopalinami (otwór W-2).

Krawczyk J., 2010b, Dokumentacja hydrogeologiczna ustalajaca zasoby eksploatacyjne ujês wód podziemnych niebêdacych kopalinami (otwory W-3, W-4, W-5).
Krishnamoorthy K., Mathew T., Mukherjee S., 2008, Normal-based methods for a gamma distribution: Prediction and tolerance intervals and stressstrength reliability. Technometrics, v. 50 (1), pp. 69-78

Loáiciga H.A., 2003, Climate Change and Ground Water: Annals of the Association of American Geographers, 93(1), pp. 30-41.

Labêdzki, L., 2006, Susze rolnicze. Zarys problematyki oraz metody monitorowania i klasyfikacji (Agricultural drought. Overview problems and methods for monitoring and classification): Water-Environment-Rural Areas. Nr 17, 107 pp.

Lupikasza, E., and Bielec-Bakowska, Z., 2005, Synoptyczne uwarunkowania dni ekstremalnych pod wzglêdem termicznym w Malopolsce w drugiej polowie XX wieku (Synoptic conditions of the thermal extereme days in $\mathrm{Ma}^{3}$ opolsca in the second half of the 20th century): Folia Geographica, v. XXXV-XXXVI, pp. 93-112.

Martinez-Landa, L., and Carrera, J., 2005, An analysis of hydraulic conductivity scale effects in granite (Full-scale Engineered Barrier Experiment (FEBEX), Grimsel, Switzerland). Water Resources Research 41, no. 3: W03006.

McDonald, M., and Harbaugh, A., 1988, A modular three-dimensional finitedifference groundwater flow model: USGS Technical Report on Modelling Techniques Book 6, USGS, Reston, VA, 596 pp.

McKee, T.B., Doesken, N.J., and Kleist, J., 1993, The relationship of drought frequency and duration to time scales. Proc. 8th Conf. of Applied Climatology, 17-22 January, Anaheim, California, pp. 179-184.

McKee, T.B., Doesken, N.J., and Kleist, J., 1995, Drought monitoring with multiple time scales. Preprints of 9th Conf. of Applied Climatology, 1520 January, Dallas, Texas, pp. 233-236.

Meehl, G.A., Stocker, T.F., Collins, W.D., Friedlingstein, P., Gaye, A.T., Gregory, J.M., Kitoh, A., Knutti, R., Murphy, J.M., Noda, A., Raper, S.C.B., Watterson, I.G., Weaver, A.J., and Zhao, Z.-C., 2007, Global climate projections, in Solomon, S., Qin, D., Manning, M., Chen, Z., Marquis, M., Averyt, K.B., Tignor, M. and Miller, H.L., eds., Climate Change 2007: The Physical Science Basis. Contribution of Working Group I to the Fourth Assessment Report of the Intergovernmental Panel on Climate Change, Cambridge University Press, Cambridge, pp. 747846.

Mrugala, S., and Shuber, P., 2004, Normalne i anomalne sumy opadów atmosferycznych w Lublinie i we Lwowie (Normal and anomalous amounts of atmospheric precipitation in Lublin and Lvov): Annales Universitations Mariae Curie-Sklodowska, v. LIX, 7, pp. 101-106.

Mustonen, S., ed., 1986, Sovellettu Hydrologia: (Applied Hydrology) Vesiyhdistys r.y., Mänttä, 503 pp.

Nalêcki, P., Resko, D., Schmalz, A., and Witczak, S., 2004, Charakterystyka parametrów hydrogeologicznych szczelinowo-porowego zloza wód leczniczych w Krynicy (Hydrogeological parameters description of fissured-porous therapeutic groundwater basin in Krynica): Biuletyn PIG 404, pp. 145-164.

Nicholls, N., Gruza, J.J., Karl, T.R., Ogallo, L.A., and Parker, D.E., 1996, Observed climate variability and change, in Climate Change 1995: The Science of Climate Change. Intergovernmental Pannel on Climate Change (IPCC). Cambridge University Press, Cambridge, 133 pp (Chapter 3).

Nyirfa, W.N., and Harron, B.H., 2001, Assessment of climate change on the agricultural resources of the Canadian prairies: Research report of the Prairie Adaptation Research Collaborative, 27 pp.

Okolowicz, W., and Martyn, D., 1989, Regiony klimatyczne (Climatic regions), in Atlas geograficzny Polski: Wyd. PPWK, Wyd. X, WarszawaWroclaw.

Oszczypko, N., 1991, Stratigraphy of the Palaegene Deposits of the Bystrica subunit (Magura Nappe, Polish Outer Carpathians): Biul. Pol. Acad. Sc., Earth Scs., v. 39 (4), pp. 415-431.

Oszczypko, N., 1998, The Western Carpathian Foredeep development of the foreland basin in front of the accretionary wedge and its burial history (Poland): Geol. Carpathica, v. 49, (6), pp. 415-431.

Oszczypko, N., Malata, E., Oszczypko-Clowes, M., and Duñczyk, L., 1999, Budowa geologiczna Krynicy (plaszczowina magurska) (Geological characterisation of the Krynica Subunit (Magura Nappe)): Przegl. Geol.. 
47, pp. 549-559.

Oszczypko, N., 2006, Geological map without deposits of Muszynka, based on geological map Oszczypko (1999), Oszczypko and Oszczypko-Clowes (2004, 2005) and detail geological map of Poland (Wêclawik and Wójcik 1995), scale 1:10 000

Paczyñski, B., 1995, Atlas hydrogeologiczny Polski 1:500 000 (Hydrogeological atlas of Poland), vol. II - Zasoby, jakosc i ochrona zwyklych wód podziemnych (Resources, quality and protection of fresh groundwater), PAE S.A., Wydawnictwo PIG, Warsaw, Poland.

Radhakrishnan, N. nad Elango, L., 2011, Study of influence of terrain and climatic factors on groundwater level fluctuation in a minor river basin using GIS. Geo-spatial Information Science, v. 14, no. 3, pp. 190-197

Rivard, C., Marion, J., Benhammane, S., Morin, A., Lefebvre, R., and Rivera, A., 2003, Étude de l'impact potentiel des changements climatiques sur les ressources en eau souterraine dans I'Est du Canada: Commission géologique du Canada, dossier public 1577, Et annexes, 39 pp.

Showstack, R., 2001, IPCC report cautiously warns of potentially dramatic climate change impact: EOS, v. 82 (9), pp. 113-120.

Stasko, S., Ciêzkowski, W., Oszczypko N., Modelska M., Buczyñski S., Olichwer T., Tarka R., and Wcislo M., 2007, Dokumentacja hydrogeologiczna w celu ustalenia zasobów zwyklych i mineralnych wód podziemnych dla górnej zlewni Muszynki: Uniwersytet Wroclawski, Wroclaw.

Szczepañski, A., and Szklarczyk, T., 2005, Zagrozenia w gospodarowaniu zasobami wód leczniczych na przykladzie rejonu Krynicy i Muszyny (Endangerings of therapeutic waters resources management - for example of Krynica and Muszyna Region): Wspólczesne Problemy Hydrogeologii t. XII, Toruñ, pp. 696-700.

Tarka, R., 1997, Zmiany polozenia zwierciadla wód podziemnych na

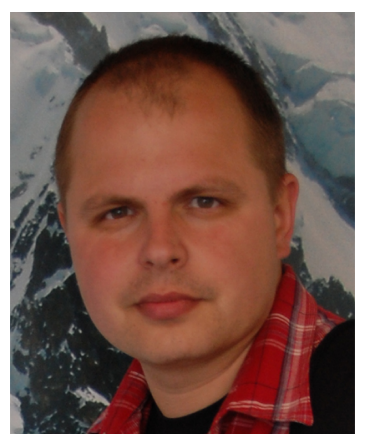

Zurek, R., 2007, The basic paths of energy flow and matter transformations in a lowland dam reservoir ecosystem: Oceanological and Hydrobiological Studies, v. XXXVI, suplement 2, pp. 5-147.

Sebastian Buczyñski received his master degree in 2001 and his Ph.D. in 2005 at the University of Wroclaw. His main research area including hydrology of springs and the hydrogeology of heterogeneous rocks - hard rocks and karst formations. During the last four years the research has been concentrated to the ground- wybranych przyk ${ }^{3}$ adach $\mathrm{z}$ obszaru Sudetów i na ich przedpolu na tle warunków opadowych (Examples of changes in groundwater level and precipitation in Sudetes and their foreland): Wspólczesne Problemy Hydrogeologii, t. VIII, Poznan, pp. 393-396.

Tomaszewska, T., 1994, Susze atmosferyczne na przestrzeni ostatniego czterdziestolecia (Atmospheric drought over the last forty years): XXV Zjazd Agrometeorologów Olsztyn-Mierki, 27-29.09.1994. Olsztyn. Wydaw. ART, pp. 169-178.

Trenberth, K.E., Jones, P.D., Ambenje, P., Bojariu, R., Easterling, D., Klein Tank, A., Parker D., Rahimzadeh, F., Renwick, J.A., Rusticucci, M., Soden, B., and Zhai, P., 2007, Observations: Surface and Atmospheric Climate Change, in Solomon, S., Qin, D., Manning, M., Chen, Z., Marquis, M.C., Averyt, K.B., Tignor, M. and Miller, H. L. eds., Climate Change 2007: The Physical Science Basis. Contribution of WG 1 to the Fourth Assessment Report of the Intergovernmental Panel on Climate Change. Cambridge University Press. Cambridge, U.K., and New York, NY, USA, pp. 235-336, plus annex online.

Witczak, S., Duñczyk, L., Motyka, J., and Oszczypko, N., 2004, Regionalny wielowarstwowy model pola hydrodynamicznego w utworach fliszu karpackiego na przyk ${ }^{3}$ adzie zlewni kryniczanki ( $\mathrm{p}^{3}$ aszczowina magurska) (Regional multilayerd model of a groundwater flow system in the Carpathians Flysch; example of the Kryniczanka watershed (Magura Nappe): Biuletyn PIG, 404, pp. 263-290.

Woldeamlak, S.T., Batelaan, O., and De Smedt, F., 2007, Effect of climate change on the groundwater system in the Grote-Nete catchment, Belgium: Hydrogeology Journal, v. 15, pp. 891-901.

Zuber, A., and Chowaniec, J., 2009, Diagenatic and other highly mineralized waters in the Polish Carpathians: Applied Geochemistry, v. 24, pp. 18891900

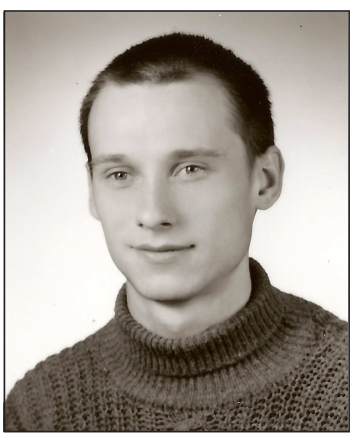

water resources especially groundwater flow systems and the conditions of the formation of groundwater resources in crystalline and sedimentary rocks.

Marek Wcislo is an assistant professor at the Univesrsity of Wroclaw. He joined the Department of Hydrogeology in 2008 and completed Ph.D. thesis concerning modelling of small basins in Sudety area in 2009. His research is focused on modelling of groundwater flow and mass transport. He also participates in regional projects connected to groundwater resources among others in Polish Carpathians. Last large research was on regional groundwater model of KGHM impact on groundwater bodies. 